\title{
AUDIT SISTEM INFORMASI AKUNTANSI SIKLUS PENGELUARAN PADA PT. LAGIO FURNITURE
}

\author{
Aries Wicaksono \\ Accounting Department, Faculty of Economic and Comunication, BINUS University \\ Jln. K.H. Syahdan No 9, Palmerah, Jakarta Barat 11480 \\ aries.wicaksono@binus.ac.id; aries.0202@gmail.com
}

\begin{abstract}
Rapid technological developments make the whole thing easier. Many companies also take advantage of these technological developments. Similarly, the corporate accounting system that uses the benefits of information technology in the form of Accounting Information Systems (AIS). PT. Lagio Furniture is a manufacturing company that produces furniture for the premium class. Information system is an important part that helps the company's operations become more effective and efficient, therefore it is important for information systems running properly.This research aimed to audit the general control and applications control on the expenditure cycle accounting information system at PT. Lagio Furniture. This type of audit is audit around the computer. And then also collecting data through observation and interviews with relevant parties. Results of the reserarch is the expenditure cycle accounting information system at PT. Lagio Furniture was good. But there is still need to be improved in the control plan security, operational management control, and control inputs.
\end{abstract}

Keywords: Auditing, System, Information, Expenditure Cycle

\begin{abstract}
ABSTRAK
Perkembangan teknologi yang sangat cepat membuat seluruh hal menjadi lebih mudah. Banyak perusahaan juga memanfaatkan perkembangan teknologi tersebut. Begitu pula dengan Sistem Akuntansi perusahaan yang memanfaatkan teknologi informasi tersebut berupa Sistem Informasi Akuntansi (SIA).PT. Lagio Furniture merupakan perusahaan manufaktur yang memproduksi furniture untuk kelas premium.Sistem informasi merupakan bagian penting yang membantu operasional perusahaan menjadi lebih efektif dan efisien, oleh karena itu penting bagi sistem informasi berjalan dengan baik.Penelitian ini bertujuan untuk mengaudit pengendalian umum serta pengendalian aplikasi yang ada pada sistem informasi akuntansi siklus pengeluaran pada PT. Lagio Furniture. Jenis audit yang digunakan adalah audit around the computer. Kemudian dilakukan juga pengumpulan data melalui observasi dan wawancara dengan pihak terkait. Hasil dari penelitian adalah sistem informasi akuntansi siklus pengeluaran pada PT. Lagio Furniture sudah baik. Tetapi masih ada perbaikan pada pengendalian rencana pengamanan, pengendalian manajemen operasional, dan pengendalian input.
\end{abstract}

Kata kunci: Audit, Sistem, Informasi, Siklus Pengeluaran 


\section{PENDAHULUAN}

Perkembangan teknologi yang sangat pesat membuat seluruh hal menjadi lebih mudah. Banyak perusahaan memanfaatkan perkembangan teknologi tersebut. Begitu pula dengan Sistem Akuntansi perusahaan yang memanfaatkan teknologi informasi tersebut yaitu Sistem Informasi Akuntansi (SIA). Sistem Informasi Akuntansi telah menjadi komponen yang sangat penting bagi keberhasilan bisnis dan organisasi. Teknologi informasi dapat membantu meningkatkan efisiensi dan efektivitas proses bisnis, pengambilan keputusan manajerial, dan kerja sama antara kelompok kerja, hingga dapat memperkuat posisi kompetitif dalam pasar yang cepat sekali berubah. Dalam proses bisnis, dibutuhkan sistem pengolahan informasi yang baik agar keputusan yang diambil merupakan keputusan yang tepat.

Penelitian ini ingin membuat evaluasi pada sistem informasi akuntansi pada sebuah perusahaan untuk menganalisis resiko dari sistem informasi perusahaan dan melihat jenis sistem informasi akuntansi serta pengendalian sistem informasi tersebut sudah berjalan baik atau sebaliknya, banyak celah untuk melakukan kesalahan atau fraud. Penelitian ini akan melakukan evaluasi sehingga dapat mengetahui apakah sistem informasi perusahaan sudah dibuat serta dikendalikan dengan baik atau tidak oleh perusahaan. Ruang lingkup yang sangat luas pada sistem informasi perusahaan dan segala keterbatasan pada penelitian ini maka penelitian ini dibatasi hanya melakukan evaluasi pada siklus pembelian sistem informasi akuntansi perusahaan.

\section{Menurut Heripracoyo (2009):}

"Masalah yang dihadapi perusahaan saat ini ialah sistem pengendalian internal yang kurang baik dalam prosedur pembelian dan pengelolaan persediaan di mana tidak terdapat dokumen pendukung yang kuat atas transaksi yang terjadi dan tidak terjadi pemisahan fungsi pembelian dan penerimaan sehingga mengakibatkan terjadi ketidaksesuaian pencatatan persediaan dengan bukti fisik persediaan yang ada.”

Penelitian ini akan membahas tentang evaluasi terhadap Sistem Informasi Siklus Pengeluaran pada PT. Lagio Furniture yang bergerak dalam bidang manufaktur. Menurut Heripracoyo (2009) "Pembelian adalah kegiatan pemilihan sumber, pemesanan dan perolehan barang dan jasa sebagai salah satu aktivitas utama operasi bisnis perusahaan.” Dan sistem informasi akuntansi siklus pengeluaran menurut Heripracoyo (2009) "merupakan sistem yang dibangun untuk mempermudah pelaksanaan pembelian dengan meng-otomatisasi-kan atau meng-komputerisasi keseluruhan maupun beberapa bagian dari proses pembelian tersebut disertai dengan pengendalian atau kontrol atas sistem komputerisasi tersebut.” Disini jelas sistem informasi akuntansi siklus pengeluaran perusahaan ini merupakan suatu hal yang dapat untuk dievaluasi. Selain itu pengeluaran juga menjadi hal yang penting dari perusahaan, jika pengeluaran kas tidak dapat dikendalikan maka resiko yang akan dialami perusahaan cukup besar, seperti kehilangan aset berupa kas, pembelian yang tidak efisien dan pengeluaran kas yang tidak seharusnya atau tidak efektif.

PT. Lagio Furniture bergerak di bidang manufaktur khusus furniture kelas premium. Produk dari PT. Lagio Furniture dipasarkan di dalam negeri maupun luar negeri. Sementara proporsi barang untuk dalam negeri masih lebih banyak sekitar 60 persen sedangkan untuk diekspor sekitar 40 persen. Pasar ekspor melingkupi Amerika Serikat, Timur Tengah dan sebagian Eropa. Berdasarkan pemikiran dan uraian diatas maka artikelini akan focus pada evaluasi sistem informasi siklus pengeluaran pada pt. Lagio furniture.

Identifikasi masalah dari penelitian ini mencakup dua hal utama yang menjadi pertanyaan dalam penelitian ini. Pertama, bagaimana sistem pengendalian di dalam sistem informasi akuntansi 
siklus pengeluaran yang ada di PT. Lagio Furniture. Kedua, apakah sistem pengendalian pada sistem informasi akuntansi siklus pengeluaran yang ada di PT. Lagio Furniture sudah efektif dan efisien. Kedua hal tersebut merupakan pertanyaaan yang akan dijawab dalam penelitian ini.

Penelitian ini mempunyai beberapa tujuan, adapun tujuan tersebut antara lain, pertama, membantu perusahaan untuk menilai sistem informasi perusahaan, kedua, mengetahui kekurangankekurangan yang ada pada sistem informasi perusahaan dan ketiga memberikan evaluasi dan rekomendasi pada perusahaan

Sementara, manfaat dari penelitian ini, antara lain, pertama, manfaat bagi peneliti yaitu agar peneliti memperoleh gambaran utuh penerapan sistem informasi pada perusahaan serta mengetahui kekurangan yang masih ada pada sistem informasi pada PT. Lagio Funiture. Kedua, manfaat bagi perusahaan yaitu agar perusahaan dapat mengetahui kinerja keseluruhan dari sistem informasi akuntansi siklus pengeluaran, khususnya dilihat dari pengendalian umum dan pengendalian aplikasi. Ketiga, manfaat bagi pihak lain yaitu memberikan sarana yang bersifat informatif serta menjadi pengembangan pihak lain untuk melakukan penelitian yang lebih lanjut.

\section{Analisis Pustaka}

Sistem informasi akuntansi muncul dari adanya sistem informasi dan sistem akuntansi. Menurut Mulyadi dalam bukunya Sistem Akuntansi (2008) "Sistem akuntansi adalah organisasi formulir, catatan, dan laporan yang dikoordinasi sedemikian rupa untuk menyediakan informasi keuangan yang memudahkan manajemen guna memudahkan pengelolaan perusahaan.” Sedangkan sistem informasi menurut Hall (2011) adalah, "The information system is the set of formal procedures by which data are collected, processed into information and distributed to users." Dengan demikian dapat diartikan bahwa sistem informasi adalah kesatuan dari prosedur formal dengan data yang dikumpulkan, diproses menjadi informasi dan didistribusikan kepada user.

Sistem informasi akuntansi sendiri memiliki pengertian menurut Rama (2008) bahwa "Sistem informasi akuntansi adalah suatu subsistem dari sistem informasi manajemen yang menyediakan informasi akuntansi dan keuangan, juga informasi lain yang diperoleh dari pengolahan rutin atas transaksi akuntansi”. Sehingga dapat disimpulkan bahwa sistem informasi akuntansi (SIA) merupakan suatu kerangka pengkordinasian sumber daya untuk mengkonversi input berupa data ekonomik menjadi keluaran berupa informasi keuangan yang digunakan untuk melaksanakan kegiatan suatu entitas dan menyediakan informasi akuntansi bagi pihak-pihak yang berkepentingan.

Audit sistem informasi memiliki pengertian menurut Romney dan Steinbart (2008) bahwa "audit sistem informasi mengkaji ulang pengendalian sistem informasi akuntansi menilai pemenuhannya dengan kebijakan dan prosedur pengendalian internal dan keefektifan perlindungan terhadap aset”. Sedangkan maksud dari audit sistem informasi dijelaskan Gondodiyoto (2009), bahwa:

"audit sistem informasi dimaksudkan untuk mengevaluasi tingkat kesesuaian antara sistem informasi dengan prosedur bisnis perusahaan atau kebutuhan pengguna, untuk mengevaluasi apakah suatu sistem informasi telah didesain dan diimplementasikan secara efektif, efisien, dan ekonomis, memilik mekanisme pengamanan aset, serta menjamin integritas data yang memadai.”

Sehingga dapat disimpulkan audit sistem informasi merupakan proses evaluasi terhadap sistem informasi berdasarkan pada prosedur pengendalian yang telah ditetapkan untuk menentukan apakah suatu sistem dapat melindungi aset, memelihara integritas data, membuat efektif serta efisien kinerja perusahaan

Tujuan audit sistem informasi menurut Romney dan Steinbart (2008), adalah untuk meninjau dan mengevaluasi pengendalian internal yang melindungi sistem tersebut. Pada saat melakukan 
audit,para auditor memiliki tujuan-tujuan berikut ini agar terpenuhi: (1) Perlengkapan keamanan melindungi perlengkapan komputer, program komunikasi dan data dari akses tidak sah, modifikasi dan penghancuran. (2) Pengembangan dan perolehan program dilaksanakan sesuai dengan otorisasi khusus dan umum dari pihak manajemen. (3) Modifikasi program dilaksanakan dengan otorisasi dan persetujuan dari pihak manajemen. (4) Pemrosesan transaksi, file, laporan, dan catatan komputer lainnya telah akurat dan lengkap. (5) Data sumber yang tidak akurat atau tidak memiliki otorisasi yang tepat diidentifikasikan dan ditangani sesuai dengan kebijakan manajerial yang telah ditetapkan. (6) File data komputer telah akurat, lengkap dan dijaga kerahasiaannya.

Menurut Seputra (2013), Audit sistem informasi dapat dibagi menjadi tiga, yaitu Audit Through The Computer, Audit Around The Computer dan Audit With The Computer.

\section{Audit Through The Computer}

Audit through the computer adalah audit yang dilakukan untuk menguji sebuah sistem informasi dalam hal proses yang terotomasi, logika pemograman, edit routines, dan pengendalian program. Pendekatan audit ini menganggap bahwa apabila program pemrosesan dalam sebuah sistem informasi telah dibangun dengan baik dan telah ada edit routines, serta pengecekan pemrograman cukup maka adanya kesalahan tidak akan terjadi tanpa terdeteksi. Jika program berjalan seperti yang direncanakan, maka semestinya output yang dihasilkan juga dapat diandalkan.

Pendekatan audit langsung ke system komputerisasi dapat digunakan pada situasi sebagai berikut: (1) Sistem aplikasi komputer memproses input yang cukup besar dan menghasilkan output yang cukup besar pula, sehingga memperluas audit untuk meneliti keabsahannya. (2) Bagian penting dari struktur pengendalian perusahaan terdapat di dalam komputerisasi yang digunakan. (3) Sistem logika komputer yang sangat kompleks dan memiliki banyak fasilitas pendukung. (4) Adanya jurang yang besar dalam melaksanakan audit secara visual, sehingga memerlukan pertimbangan antara biaya dan manfaatnya.

\section{Audit Around The Computer}

Audit around the computer adalah pendekatan audit dimana auditor menguji keandalan sebuah informasi yang dihasilkan oleh komputer dengan terlebih dahulu mengkalkulasikan hasil dari sebuah transaksi yang dimasukkan kedalam sistem. Kemudian kalkulasi tersebut dibandingkan dengan output yang dihasilkan oleh sistem. Apabila valid dan akurat, dapat diasumsikan bahwa pengendalian sistem telah efektif dan sistem telah beroperasi dengan baik.

Metode audit di sekitar komputer tersebut dapat digunakan pada situasi sebagai berikut: (1) Dokumen sumber tersedia dalam bentuk kertas dan dapat dilihat secara visual. (2) Dokumen-dokumen yang disimpan dalam file mudah untuk ditemukan. (3) Sistem komputer yang digunakan standar atau sederhana. (4) Sistem komputer yang digunakan masih menggunakan software yang umum digunakan, dan telah diakui, serta digunakan secara massal.

\section{Audit With The Computer}

Audit with the computer disebut juga dengan teknik audit berbantuan komputer atau penggunaan komputer untuk membantu pelaksanaan audit. Contoh dari audit with the computer yaitu auditor melakukan audit dengan menggunakan ACL atau excel dalam proses auditnya. Terdapat beberapa cara yang dapat digunakan oleh auditor dalam melaksanakan prosedur audit: (1) Memproses atau melakukan pengujian dengan menggunakan komputer klien itu sendiri sebagai bagian dari pengujian pengendalian. (2) Menggunakan komputer untuk melaksanakan tugas audit yang terpisah dari catatan klien, yaitu mengambil copy data file atau program milik klien untuk diuji dengan komputer lain di kantor auditor. 
Pengendalian sistem informasi berbasis komputer menurut Hall (2011) terdiri dari pengendalian umum (general control) dan pengendalian aplikasi (application control). Adapun komponen dari pengendalian umum, antara lain: (1) Penyusunan rencana pengamanan. (2) Pemisahan tugas dalam fungsi sistem. (3) Pengendalian proyek penyusunan sistem informasi. (4) Pengendalian akses fisik. (5) Pengendalian akses logis. (6) Pengendalian penyimpanan data. (7) Pengawasan transmisi data. (8) Standar dokumentasi. (9) Minimalisasi waktu penghentian sistem. (10) Perencanaan pemulihan dari bencana. (11) Perlindungan terhadap PC dan fasilitas jaringan. (12) Pengendalian internet

Sementara khusus untuk pengendalian aplikasi terdiri dari tiga komponen besar yang mempunyai keterkaitan satu sama lain, yaitu : (1) Boundary control. (2) Input control. (3) Output control.

Rangkuman kajian teoritik yang telah dianalisis dapat dilihat dalam tabel sebagai berikut :

Tabel 1 Rangkuman Kajian Teoritik

\begin{tabular}{|c|c|c|c|}
\hline No & Sumber Teori & Penjelasan & Hubungan Penelitian \\
\hline 1 & Rama (2009) & $\begin{array}{l}\text { Sistem informasi akuntansi adalah suatu } \\
\text { subsistem dari sistem informasi manajemen yang } \\
\text { menyediakan informasi akuntansi dan keuangan, } \\
\text { juga informasi lain yang diperoleh dari } \\
\text { pengolahan rutin atas transaksi akuntansi” }\end{array}$ & $\begin{array}{l}\text { Sistem informasi } \\
\text { akuntansi merupakan } \\
\text { media yang mengolah } \\
\text { data akuntansi menjadi } \\
\text { informasi akuntansi. }\end{array}$ \\
\hline 2 & Gondodiyoto (2009) & $\begin{array}{l}\text { audit sistem informasi dimaksudkan untuk } \\
\text { mengevaluasi tingkat kesesuaian antara sistem } \\
\text { informasi dengan prosedur bisnis perusahaan } \\
\text { atau kebutuhan pengguna, untuk mengevaluasi } \\
\text { apakah suatu sistem informasi telah didesain dan } \\
\text { diimplementasikan secara efektif, efisien, dan } \\
\text { ekonomis, memilik mekanisme pengamanan } \\
\text { aset, serta menjamin integritas data yang } \\
\text { memadai }\end{array}$ & $\begin{array}{l}\text { Audit sistem informasi } \\
\text { ditujukan untuk } \\
\text { mengevaluasi efektivitas, } \\
\text { efisiensi dan ekonomis } \\
\text { serta pengendalian yang } \\
\text { ada di dalamnya. }\end{array}$ \\
\hline 3. & Seputra (2013) & $\begin{array}{l}\text { Metodologi dalam melakukan audit sistem } \\
\text { informasi terdiri dari tiga metode yaitu audit } \\
\text { around the computer, audit through the computer } \\
\text { dan audit with the computer. }\end{array}$ & $\begin{array}{l}\text { Pendekatan yang } \\
\text { dilakukan dengan audit } \\
\text { around the computer. }\end{array}$ \\
\hline 4 & Gondodiyoto (2009) & $\begin{array}{l}\text { Pengendalian yang ada pada sistem informasi } \\
\text { terdiri dari pengendalian umum (general } \\
\text { control) dan pengendalian aplikasi (application } \\
\text { control) }\end{array}$ & $\begin{array}{l}\text { Fokus utama kepada } \\
\text { pengendalian umum dan } \\
\text { pengendalian aplikasi }\end{array}$ \\
\hline \multirow[t]{2}{*}{5} & Hall (2011) & $\begin{array}{l}\text { Pengendalian umum atau general control terdiri } \\
\text { dari penyusunan rencana pengamanan, } \\
\text { pemisahan tugas dalam fungsi sistem, } \\
\text { pengendalian proyek penyusunan sistem } \\
\text { informasi, pengendalian akses fisik, } \\
\text { pengendalian akses logik, pengendalian } \\
\text { penyimpanan data, pengawasan transmisi data, } \\
\text { standar dokumentasi, minimalisasi waktu } \\
\text { penghentian sistem, perencanaan pemulihan } \\
\text { terhadap bencana, perlindungan terhadap PC dan } \\
\text { fasilitas jaringan, pengendalian internet. }\end{array}$ & $\begin{array}{l}\text { Audit dilakukan dengan } \\
\text { mengevaluasi fungsi } \\
\text { pengendalian umum atau } \\
\text { general control serta } \\
\text { fungsi pengendalian } \\
\text { aplikasi atau application } \\
\text { control. }\end{array}$ \\
\hline & & $\begin{array}{l}\text { Pengendalian aplikasi atau application control } \\
\text { terdiri dari pengendalian input, pengendalian } \\
\text { boundary, dan pengendalian output. }\end{array}$ & \\
\hline
\end{tabular}




\section{METODE}

Penelitian terhadap sistem informasi akuntansi pengeluaran kas dilakukan dengan menggunakan metode audit around the computer di mana auditor menguji keandalan sebuah informasi yang dihasilkan oleh komputer dengan terlebih dahulu mengkalkulasikan hasil dari sebuah transaksi yang dimasukkan kedalam sistem. Kemudian kalkulasi tersebut dibandingkan dengan output yang dihasilkan oleh sistem. Apabila valid dan akurat, dapat diasumsikan bahwa pengendalian sistem telah efektif dan sistem telah beroperasi dengan baik. Selain itu dilakukan observasi serta wawancara terhadap pengguna maupun pihak yang terkait dengan sistem informasi akuntansi pengeluaran kas pada PT. Lagio Furniture.

\section{HASIL DAN PEMBAHASAN}

\section{Perencanaan Audit}

Untuk melakukan audit sistem informasi, maka diperlukan perencanaan audit yang matang. Fungsi dari perencanaan audit adalah memberikan panduan mengenai prosedur yang akan dilakukan ketika melakukan audit sistem informasi, selain prosedur-prosedur audit juga dibatasi batasan-batasan ruang lingkup audit yang akan diaudit, sehingga proses audit sistem informasi fokus pada objek yang akan diaudit. Tujuan khusus dilakukannya audit sistem informasi akuntansi siklus pengeluaran pada PT. Lagio Furniture adalah untuk mengevaluasi sistem informasi akuntansi siklus pengeluaran dengan melakukan penilaian terhadap security management control, operational management control, boundary control, input control dan output control. Selain itu audit sistem informasi akuntansi siklus pengeluaran juga bertujuan untuk mendeteksi risiko potensial dari sistem informasi akuntansi siklus pengeluaran pada PT. Lagio Furniture. Kemudian akan diberikan rekomendasi terkait dengan temuan yang ada.

Ruang lingkup audit sistem informasi akuntansi siklus pengeluaran pada PT.Lagio Furniture adalah sebagai berikut: (1) Pengendalian umum (General Control) meliputi pengendalian manajemen keamanan serta pengendalian manejemen operasional. (2) Pengendalian aplikasi (Application Control) meliputi boundary control, input control dan output control.

Prosedur dalam melakukan audit sistem informasi siklus pengeluaran pada PT. Lagio Furniture adalah sebagai berikut: (1) Observasi - Observasi dilakukan dengan melihat secara langsung operasional bisnis di perusahaan khususnya terkait dengan proses bisnis yang terkait dengan sistem informasi akuntansi siklus pengeluaran pada PT. Lagio Furniture. Proses bisnis yang terkait yaitu proses pemesanan, penerimaan barang, persetujuan invoice dari supplier, serta proses pengeluaran kas untuk pembayaran.Selain itu dilakukan pengujian atas sistem informasi akuntansi siklus pegeluaran dengan menginput data langsung ke sistem serta membandingkannya dengan hasil output yang dihasilkan sistem tersebut. (2) Wawancara - Membuat daftar pertanyaan untuk digunakan mewawancarai staf yang bersangkutan dalam bidang pembelian antara lain Accounting and Finance Manager, Accounting Staff, dan seterusnya. Adapun panduan untuk membantu wawancara yang dilakukan yaitu checklist untuk membantu penilaian dari pengendalian umum serta pengendalian aplikasi.

Susunan checklist sebagai berikut: (1) Checklist pada Pengendalian Umum, terdiri dari Pengendalian Manajemen Keamanan dan Pengendalian Manajemen Operasional. (2) Checklist Pada Pengendalian Aplikasi terdiri dari Boundary Control, Input Control dan Output Control. 


\section{Hasil Audit}

Evaluasi awal yang dilakukan pada proses audit sistem informasi akuntansi siklus pengeluaran pada PT. Lagio Furniture adalah pengendalian manajemen keamanan. Terkait dengan pengendalian manajemen keamanan ada beberapa hal yang sudah menjadi poin positif, antara lain: (1) Perusahaan memiliki alat pemadam kebakaran yang memadai sesuai dengan standar dari dinas pemadam kebakaran. (2) Jumlah alat pemadam kebakaran cukup memadai sesuai dengan luas area bangunan pabrik dan letak dari alat pemadam tersebut cukup strategis. (3) Setiap komputer memiliki UPS untuk menjaga agar komputer tidak langsung mati ketika ada pemadaman listrik. (4) Setiap ruangan memiliki CCTV atau kamera pengawas dan terletak di tempat yang strategis. (5) Perusahaan mempunyai aturan yang ketat terkait dengan larangan merokok di lingkungan pabrik serta gedung manajemen. (6) Server ditempatkan pada lantai dua gedung manajemen, serta mempunyai aturan pembatasan akses ke dalam ruang server. (7) Akses ke dalam area perusahaan dibatasi mulai dari pintu masuk ditanyakan keperluannya, kemudian jika akan masuk ke gedung manajemen harus meninggalkan tanda pengenal jika berasal dari luar perusahaan. (8) PT. Lagio Furniture mempunyai prosedur backup data secara berkala, prosedur itu mengharuskan karyawan yang menggunakan komputer untuk melakukan backup terhadap data di komputer ke external hard drive. (9) Setiap komputer terpasang antivirus di dalamnya. (10) PT. Lagio Furniture juga mengasuransikan semua fasilitas dan asset yang ada di gedung manajemen serta pabrik apabila terjadi kebakaran.

Selain hal yang positif, ada temuan yang didapat dalam pengendalian manajemen keamanan, yaitu: (1) Tidak adanya detektor asap di lingkungan gedung manajemen. (2) Antivirus yang ada di setiap komputer tidak semua ter-update.

Hal tersebut dapat mengakibatkan timbulnya risiko yang dapat muncul yaitu kebakaran karena jika ada asap maka tidak terdeteksi lebih cepat. Kemudian risiko jaringan komputer atau PC yang terkena virus juga dapat muncul karena antivirus yang terpasang di komputer atau PC tidak ter-update antivirusnya. Oleh karena itu rekomendasi yang dapat diberikan yaitu: (1) Memasang detektor asap di semua ruangan, sebagai pendeteksi asap yang kemungkinan muncul dari benda yang terbakar. (2) Membuat prosedur rutin untuk mengupdate antivirus bisa melalui masing-masing komputer atau melalui server secara langsung.

Evaluasi selanjutnya adalah terhadap pengendalian manajemen operasional. Pengendalian ini menekankan kepada masalah yang bersifat fisik terkait operasional bisnis. Dari hasil observasi dan wawancara yang telah dilakukan kemudian berdasarkan check list yang ada terkait dengan pengendalian manajemen operasional dapat dicatat poin-poin positif sebagai berikut: (1) Perusahaan telah memiliki struktur organisasi yang jelas dari tingkat manajemen atas sampai dengan tingkat staf. (2) Perusahaan telah memiliki standar operasional prosedur terkait pelaksanaan pekerjaan, sasaran kinerja sistem informasi, prosedur pengentrian data, dan prosedur perawatan perangkat keras (hardware) maupun perangkat lunak (software). (3) Adanya pelatihan bagi karyawan baru terkait dengan penggunaan sistem, sehingga meminimalisasi kesalahan penggunaan sistem akibat pelatihan yang kurang. (4) Adanya pengendalian terhadap absensi karyawan melalui sistem fingerprint.

Pada pengendalian manajemen operasional terdapat beberapa temuan, antara lain: (1) Pada proses penerimaan bahan baku terjadi ketidaksesuaian antara barang yang diterima dengan jumlah yang masuk ke dalam gudang. (2) Tidak ada prosedur stock opname secara berkala, untuk mengecek jumlah stok persediaan bahan baku.

Dari kedua temuan di atas dapat menyebabkan risiko ketidakakuratan nilai persediaan yang tercatat. Kemudian dapat menimbulkan kerugian bagi perusahaan karena barang yang masuk ke gudang tidak sesuai dengan pesanan dari perusahaan kepada pemasok atau supplier. Untuk meminimalikan risiko tersebut maka dapat diberikan rekomendasi sebagai berikut: (1) Penghitungan barang yang diterima dengan sistem barcode, sehingga barang yang masuk tidak dihitung secara 
manual tetapi menggunakan sistem barcode. Jika tidak memungkinkan maka penghitungan dilakukan dengan cara bertahap dan dilakukan lebih dari satu orang staf, sehingga bisa terjadi cross check diantara keduanya. (2) Dibuat prosedur stock opname secara berkala, bisa mingguan atau bulanan. Sehingga jika ada ketidaksesuaian jumlah barang di gudang dapat diketahui lebih awal.

Selanjutnya setelah menganalisis pengendalian umum maka dilakukan audit terhadap pengendalian aplikasi, audit dimulai dari komponen yang pertama yaitu pengendalian boundary. Dari pengendalian boundary dapat dicatat beberapa poin positif yaitu: (1) Adanya identifikasi khusus jika ingin mengakses sistem informasi akuntansi pengeluaran berupa username dan password. (2) Password yang diset harus terdiri dari angka dan huruf kemudian huruf kecil dan huruf besar, sehingga dari segi keamanan lebih baik. (3) Adanya prosedur penggantian password secara berkala. (6) Aplikasi diatur sesuai dengan fungsi dan wewenang masing-masing user atau pengguna.

Setelah dilakukan observasi, wawancara, serta pengujian dengan menggunakan password yang salah maka tidak diketemukan adanya temuan pada pengendalian boundary. Pengendalian yang diuji setelah pengendalian boundary adalah pengendali input. Pada pengendalian input dilakukan audit yang berfokus kepada proses input data pada sistem informasi akuntansi siklus pengeluaran, dari proses audit tersebut ada hal positif yang menjadi catatan yaitu: (1) Tampilan sangat user friendly sehingga memudahkan dalam penggunaan aplikasi. (2) Pada menu tampilan Purchase Order, sudah sesuai dengan Purchase Order manual dan data tergambar secara rinci. (3) Ada verifikasi data yang di-input melalui menu pop up verifikasi data yang di-input. (4) Ada penolakan jika data yang di-input salah.

Dalam pengendalian input tidak ada informasi terkait data yang akan di-input, hal tersebut dapat menimbulkan risiko adanya salah input data. Untuk itu rekomendasi yang dapat diberikan adalah ditambahkannya fasilitas help terkait data yang akan di-input. Kemudian audit selanjutnya adalah terhadap pengendalian output. Pada pengendalian output yang diaudit adalah berfokus kepada pelaporan atau reporting. Untuk pengendalian output ada beberapa hal positif yang menjadi catatan. Hal-hal positif tersebut adalah sebagai berikut: (1) Laporan yang dihasilkan terkait pembelian dan pengeluaran kas sudah sesuai dengan harapan dari manajemen, sehingga dapat membantu proses pengambilan keputusan. (2) Laporan dihasilkan dengan sangat cepat, sehingga dapat dihasilkan ketika ada manajemen membutuhkan secara mendadak. (3) Laporan-laporan hanya bisa dicetak atau dihasilkan oleh orang yang berwenang, dan diotorisasi.

Setelah dilakukan observasi, wawancara, serta pengujian dengan menggunakan password yang salah maka tidak diketemukan adanya temuan pada pengendalian output.

\section{SIMPULAN}

Berdasarkan hasil evaluasi sistem pengendalian sistem informasi akuntansi siklus pengeluaran pada PT. Lagio Furniture., dapat disimpulkan bahwa pengendalian sistem informasi pada perusahaan sudah sangat baik tetapi dengan proses bisnis yang terus berkembang maka perusahaan harus selalu mengembangkan sistem informasi akuntansi siklus pengeluaran sesuai kebutuhan yang diperlukan agar sistem informasi akuntansi siklus pengeluaran perusahaan menjadi lebih baik lagi.

Untuk pengendalian manajemen keamanan sudah cukup baik. Walaupun sudah cukup baik ada beberapa hal yang harus menjadi perhatian terutama terkait dengan risiko terjadinya kebakaran dengan menambahkan fungsi detektor asap, kemudian terkait dengan risiko keamanan berkomputer perlu adanya prosedur update antivirus sehingga meminimalisir infeksi virus yang menyerang komputer atau jaringan. Pengendalian manajemen operasional masih ada yang perlu diperbaiki, 
pertama adalah pada proses penerimaan barang diperlukan solusi terhadap masalah ketidaksesuain penghitungan barang yang masuk ke gudang dengan yang dipesan. Yang kedua adalah perlu ada prosedur stok opname, untuk mengecek kesesuaian barang yang ada digudang dengan catatan perusahaan.

Pada pengendalian boundary sudah sangat baik karena tidak diketemukan terkait masalah pengendalian boundary. Pada pengendalian input sudah baik. Tetapi ada hal yang terkait dengan tidak adanya fasilitas bantuan informasi mengenai peng-input-an data. Pada pengendalian output sudah sangat baik, tidak ada temuan setelah proses audit dilakukan di dalam proses pengendalian output.

Berdasarkan simpulan yang telah diuraikan, ada beberapa saran untuk memperbaiki kesalahan serta mengembangkan perusahaan pada pengendalian sistem informasi akuntansi siklus pengeluaran perusahaan menjadi lebih baik, yaitu: (1) Menambahkan fungsi detektor asap sehingga dapat mendeteksi terjadinya pemicu kebakaran lebih awal. (2) Perlu dibuat prosedur update antivirus secara berkala, sehingga meminimalisir terjadinya serangan virus terhadap PC atau jaringan. (3) Menambahkan fungsi bantuan ketika proses input akan dilakukan sehingga meminimalisir terjadinya kesalahan input.

\section{DAFTAR PUSTAKA}

Gondodiyoto, S. (2009). Audit Sistem Informasi + Pendekatan CobIT (Edisi Revisi). Jakarta: Mitra Wacana Media.

Hall, J. R. (2011). IT Auditing. USA: South Western Cengage Learning.

Heripracoyo, S. (2009). Seminar Nasional Aplikasi Teknologi Informasi (SNATI 2009). Diakses dari http://journal.uii.ac.id/index.php/Snati/article/viewFile/1084/982.

Mulyadi. (2008). Sistem Akuntansi . Jakarta: Penerbit Salemba Empat.

Rama, J. (2009). Sistem Informasi Akuntansi. Jakarta: Salemba Empat.

Romney, M. B. \& Steinbart, J. P. (2008). Accounting Information System. Jakarta: Penerbit Salemba Empat.

Seputra, A., Eka, Y. (2013). Belajar Tuntas Audit Berbantuan Komputer. Yogyakarta: Penerbit Gava Media. 